\title{
ANALISIS PERAN PEJABAT PEMBINA KEPEGAWAIAN DAN PEJABAT YANG BERWENANG DALAM PEMBINAAN ASN DI INSTANSI PEMERINTAH \\ (STUDI: KABUPATEN LAMPUNG UTARA, KOTA CILEGON, DAN KOTA KEDIRI)
}

\author{
THE ANALYSIS OF CIVIL SERVICE ADVISOR OFFICIALS ROLE AND \\ AUTHORIZED OFFICIALS IN THE ASN DEVELOPMENT \\ AT GOVERNMENT INSTITUTION \\ (STUDY: DISTRICT NORTH LAMPUNG, CILEGON CITY, AND KEDIRI CITY)
}

\author{
Ajib Rakhmawanto \\ Pusat Pengkajian dan Penelitian Badan Kepegawaian Negara \\ Jl. Letjen Soetoyo 12 Cililitan Jakarta Timur \\ Telp/Fax. 021.80887011, 081310201165 \\ Email: ajib.bkn@gmail.com \\ Dikirim: 11 Mei 2015 Direvisi: 6 Juni 2015 Disetujui: 17 Juli 2015
}

\begin{abstract}
Abstrak
Tujuan penelitian ini; pertama, menganalisis peran Pejabat Pembina Kepegawaian dan Pejabat Yang Berwenang dalam sistem pembinaan ASN sebagaimana tertuang dalam UU ASN; kedua, mengidentifikasi implementasi sistem pembinaan PNS yang telah dijalankan instansi pemerintah. Pendekatan penelitian yang digunakan deskriptif kualitatif dengan informan akademisi SDM publik dan praktisi pengelola SDM ASN di beberapa instansi pemerintah. Teknik pengambilan data penelitian dengan cara FGD dan wawancara. Hasil penelitian menunjukan; pertama, sistem pembinaan ASN dilakukan oleh Pejabat Pembina Kepegawaian yang berperan sebagai pengambil kebijakan dan Pejabat Yang Berwenang yang berperan sebagai pelaksana teknis kebijakan; kedua, implementasi pembinaan PNS di instansi pemerintah yang telah berjalan selama ini kurang obyektif karena mengabaikan prinsip merit dan banyak kepentingan politik. Rekomendasi penelitian; pertama, menciptakan kode etik penyelenggaraan pembinaan ASN, dan adanya koordinasi antara Pejabat Pembina Kepegawaian dan Pejabat Yang Berwenang dalam mejalankan peran, tugas, dan fungsinya masing-masing. Kedua, lembaga pengawas (Deputi Pengawasan dan Pengendalian BKN) melakukan pemantauan secara intensif terhadap pembinaan pegawai ASN, dan memberikan sanksi tegas terhadap segala bentuk pelanggaran dalam penyelenggaraan manajemen ASN.
\end{abstract}

Kata kunci: ASN, Pembinaan ASN, Pejabat Pembina Kepegawaian, Pejabat Yang Berwenang

\begin{abstract}
The purpose of this research; first, to analyze the role of Civil Service Advisor Officials and Authorized Officials in the development system as mentioned in the State Apparatus Law. Second, to identify the implementation of civil servant development system that conducted by the government. This research used descriptive qualitative approach with informants from the public human resources academician and practitioners from human resources managers in several government agencies. The technique used to take the reserach data was using Focus Group Discussion and interview. The research results shows; first, state apparatus development system was conducted by civil service Advisor Official whose role is as decision maker and authorized officials whose role is as technical policy executives. Second, the on going state apparatus development system in the government environtment is ignoring the merit system. The recommendation of the research; first providing the ASN management code of conduct and a coordination between civil service advisor official and authorized officials in conducting their roles and function. Second, the supervisory institution (Supervisory Deputy in BKN) monitor the implementation of ASN management intensively, and pose a sanction against all form of breach in the ASN management.
\end{abstract}

Keywords: ASN, State Appartus Development, Civil Service Advisor Officials, Authorized Officials 


\section{PENDAHULUAN}

Reformasi birokrasi hakikatnya merupakan upaya untuk melakukan perubahan terhadap sistem penyelenggaraan pemerintahan yang menyangkut aspek kelembagaan (organization), ketatalaksanaan (business process), dan sumberdaya manusia aparatur (human capital). Tiga komponen kunci dalam birokrasi pemerintahan ini merupkan suatu sistem yang saling berkaitan dan tidak bisa dipisahkan satu sama lain. Sehingga pembenahan terhadap ketiga komponen ini idealnya harus dilakukan secara bersamaan. Reformasi birokrasi pemerintahan sangat mendesak dilakukan mengingat banyak sorotan publik atas kelembagaan yang gemuk, tatalaksana yang tidak jelas, serta kualitas sumber daya aparatur yang rendah. Berbagai permasalahan dalam birokrasi telah mengakibatkan sistem penyelenggaraan pemerintah tidak berjalan secara efektif dan efisien sehingga perlu segera ditata ulang kembali. Publik sangat berharap bahwa reformasi birokrasi akan diikuti perubahan mendasar pada desain kehidupan bermasyarakat, berbangsa, dan bernegara.

Perubahan ini menyangkut berbagai dimensi, diantaranya; masalah ekonomi, sosial, politik, dan budaya. Perubahan budaya (culture) sebagai pola pembangunan karakter dalam birokrasi pemerintahan mendesak untuk segera dibenahi. Hal ini mengingat culture pada birokrasi punya kontribusi besar terhadap keberhasilan pemerintah dalam menjalankan tugas pokoknya sebagai pelayanan publik (public service). Harapan terbentuknya birokrasi yang bersih dan profesional harus segera direalisasikan dengan melakukan pembinaan aparatur negara. Aparatur Sipil Negara (ASN) sebagai pilar utama birokrasi pemerintahan, perlu dibina dan dikembangkan secara profesional tujuannya untuk membangun kepercayaan masyarakat (public trust building) dan menghilangkan citra buruk birokrasi pemerintahan yang selama ini berkembang. Pembinaan ASN memerlukan komitmen bersama yang tidak mudah dilakukan. Berdasarkah hasil penelitian terdapat faktor dominan yang mempengaruhi pembinaan sumber daya aparatur Pegawai Negeri Sipil (PNS) yaitu komitmen pimpinan yang kuat dalam melakukan pembinaan (Yuslim, dkk: 2013:171).

Pegawai ASN berdasarkan pertumbuhan per Juni 2014 untuk Pegawai Negeri Sipil (PNS) jumlahnya mencapai 4.375.009 orang (Data Statistik INKA BKN, 2014:1), hal ini merupakan aset negara yang perlu manage dengan baik. Paradigma baru manajemen ASN memandang perlu ada perubahan dalam pengelolaan ASN, dari perspektif lama manajemen kepegawaian yang menekankan pada hak dan kewajiban individual pegawai menuju pespektif baru yang menekankan pada manajemen pengembangan sumber daya manusia secara strategis (strategic human resource management) (Naskah Akademik UU ASN). Persepsi ini dimaksudkan agar selalu tersedia pegawai ASN yang unggul, kompeten, dan kompetitif selaras dengan dinamika perubahan lingkungan strategis yang terus maju dan berkembang.

Merubah pola manajemen ASN secara strategis merupakan pekerjaan yang tidak mudah bagi institusi yang diberikan tugas untuk menyelenggarakan manajemen ASN. Hal ini mengingat sejarah dan budaya birokrasi pemerintahan di Indonesia selalu dipengaruhi oleh dominasi peran politik dan kekuasaan. Aspek politik dan kekuasaan dalam pemerintahan merupakan kesatuan tidak terpisahkan yang menyebabkan konflik kepentingan dan kadang mengesampingkan nilai-nilai etika. Tarik menarik politik dan kekuasaan sangat berpengaruh terhadap pergeseran fungsi dan peran birokrasi pemerintah. Birokrasi yang seharusnya bekerja melayani dan berpihak kepada rakyat, berkembang menjadi melayani penguasa dan berpihak pada politik dan kekuasaan. Ini sering terjadi pasca pemilu dimana pengisian jabatan dalam organisasi birokrasi lebih merupakan bagi-bagi jatah kekuasaan politik pada lingkungan internal organisasi pemerintah tanpa mempertimbangkan aspek efesiensi dan efektivitas jabatan dalam penyelenggaraan pelayanan publik (Wicaksono dan Ismail, 2013:164). Dampaknya Untuk mendapatkan jabatan dan berkembangnya pegawai dihadapkan pada peluang yang diperebutkan secara tidak profesional (Sulistiyani, 2010:229).

Dalam sistem pembinaan ASN terdapat 2 (dua) Pejabat kunci yang mempunyai peranan penting kaitanya dengan penyelenggaraan manajemen ASN. Pejabat tersebut sebagaimana tertuang pada Bab VIII Pasal 52 bagian kedua Undang-Undang (UU) Nomor 5 Tahun 2014, terdapat Pejabat Pembina Kepegwaian dan Pejabat Yang Berwenang dalam manajemen ASN. Disinilah urgensinya melakukan penelitian tentang “Analisis Peran Pejabat Pembina Kepegawaian dan Pejabat Yang Berwenang Dalam Pembinaan ASN Di Instansi Pemerintah”. Penelitian ini membatasi pada dua pokok permasalahan; pertama, bagaimanakah peran Pejabat Pembina Kepegawaian dan Pejabat Yang Berwenang dalam sistem pembinaan ASN; kedua, bagaimanakah implementasi sistem pembinaan PNS yang selama ini diterapkan oleh instansi pemerintah. Adapun tujuan penelitian ini adalah; pertama, menganalisis peran Pejabat Pembina Kepegawaian dan Pejabat Yang Berwenang dalam sistem pembinaan ASN sebagaimana tertuang dalam UU Nomor 5 Tahun 2014; kedua, mengidentifikasi sistem pembinaan PNS yang selama ini sudah diterapkan instansi pemerintah.

\section{METODE}

Penelitian ini menggunakan pendekatan deskriptif kualitatif. Data primer penelitian digali dengan teknik FGD Focus Group Discussion (FGD) 
dan wawancara (interview) berupa hasil rekaman, catatan, dan notulen, sedangkan data sekunder penelitian digali dengan studi literatur berupa hasil review buku-buku referensi, jurnal, media masa, dan peraturan perundang undangan terkait dengan ASN. Informan penelitian yaitu tim penyusun RPP ASN (RPP Manajemen ASN, RPP Manajemen PPPK, RPP Penilaian Kinerja dan Disiplin PNS) dan penyelenggara manajemen ASN di Pemerintah Daerah (Sekda, Kepala BKD, Kepala Inspektorat). Lokasi penelitian sesuai jadwal tentatif pelaksanaan rapat/FGD tim penyusun RPP ASN, sedangkan untuk FGD dan wawancara berkaitan dengan penyelenggara manajemen ASN/implementasi pembinaan ASN yaitu di Pemerintah Kabupaten Lampung Utara, Kota Cilegon, dan Kota Kediri. Pengumpulan data dilakukan 4 (empat) bulan, dari bulan Juni sampai dengan September 2014. Analisis data menggunakan model yang dikembangkan oleh Milles dan Huberman, yaitu melalui tiga jalur kegiatan: pertama, reduksi data; kedua, penyajian data; dan ketiga, penarikan kesimpulan/verifikasi (Sugiyono, (2012:334).

\section{HASIL DAN PEMBAHASAN}

\section{Aparatur Sipil Negara}

ASN sebagaimana tertuang dalam UndangUndang Nomor 5 Tahun 2014 adalah merupakan sebuah profesi bagi PNS dan PPPK yang bekerja pada instansi pemerintah. Pegawai ASN adalah PNS dan PPPK yang diangkat oleh Pejabat Pembina Kepegawaian dan diserahi tugas dalam suatu jabatan pemerintahan atau diserahi tugas negara lainnya dan digaji berdasarkan Per UU. PNS adalah WNI yang memenuhi syarat tertentu, diangkat sebagai pegawai ASN secara tetap oleh Pejabat Pembina Kepegawaian untuk menduduki jabatan pemerintahan. PPPK adalah WNI yang memenuhi syarat tertentu, diangkat berdasarkan perjanjian kerja untuk jangka waktu tertentu dalam rangka melaksanakan tugas pemerintahan. Untuk mewujudkan dan menciptakan pegawai ASN yang berkualitas perlu penyelenggaraan manajemen ASN berdasarkan sistem merit. Menurut Toha sistem merit menekankan profesionalisme pada pengisian jabatanjabatan dalam birokrasi pemerintahan, dimana apabila ada seorang pegawai yang mempunyai kompetensi dan keahlian sesuai dengan yang dibutuhkan pada suatu jabatan, bisa diangkat untuk menduduki jabatan tersebut (Rahmawanto, 2013:31).

Jabatan dalam ASN terdiri dari Jabatan Administrasi, Jabatan Fungsional, dan Jabatan Pimpinan Tinggi. Jabatan Administrasi adalah sekelompok jabatan yang berisi fungsi dan tugas berkaitan dengan pelayanan publik serta administrasi pemerintahan dan pembangunan. Jabatan Fungsional adalah sekelompok jabatan yang berisi fungsi dan tugas berkaitan dengan pelayanan fungsional yang berdasarkan pada keahlian dan keterampilan tertentu. Jabatan Pimpinan Tinggi adalah sekelompok jabatan tinggi pada instansi pemerintah. Jabatan Administrasi terdiri atas 3 (tiga) tingkatan jabatan, yaitu; (a) Jabatan Administrator; (b) Jabatan Pengawas; (c) Jabatan Pelaksana. Jabatan Fungsional terdiri atas 2 (dua) tingkatan jabatan, yaitu; (a) Jabatan Fungsional Keahlian (Utama, Madya, Muda, Pertama); (b) Jabatan Fungsional Keterampilan (Penyelia, Mahir, Terampil, Pemula). Jabatan Pimpinan Tinggi terdiri atas 3 (tiga) tingkatan jabatan, yaitu; (a) Jabatan Pimpinan Tinggi Utama; (b) Jabatan Pimpinan Tinggi Madya; (c) Jabatan Pimpinan Tinggi Pratama.

Peran pegawai ASN sebagai perencana, pelaksana, dan pengawas penyelenggaraan tugas umum pemerintahan dan pembangunan nasional melalui pelaksanaan kebijakan dan pelayanan publik yang profesional, bebas dari intervensi politik, serta bersih dari praktik KKN. Pegawai ASN berfungsi sebagai pelaksana kebijakan publik, pelayan publik, serta perekat dan pemersatu bangsa. Pegawai ASN bertugas; (a) Melaksanakan kebijakan publik yang dibuat oleh Pejabat Pembina Kepegawaian sesuai dengan ketentuan Per-UU; (b) Memberikan pelayanan publik yang profesional dan berkualitas; (c) Mempererat persatuan dan kesatuan NKRI. Disamping bertugas melaksanakan kebijakan publik, memberikan pelayanan publik, dan mempererat persatuan kesatuan bangsa, pegawai ASN juga diserahi tugas untuk melaksanakan tugas pemerintahan dan tugas pembangunan.Tugas pemerintahan dilaksanakan dalam rangka penyelenggaraan fungsi umum pemerintahan yang meliputi pendayagunaan kelembagaan, kepegawaian, dan ketatalaksanaan. Sedangkan dalam rangka pelaksanaan tugas pembangunan tertentu dilakukan melalui pembangunan bangsa (cultural and political development) serta melakukan pembangunan ekonomi dan sosial (economic and social development) yang diarahkan pada peningkatan kesejahteraan dan kemakmuran masyarakat.

Untuk memperjuangkan hak dan kewajiban, menegakan etika profesi, serta membangun jiwa korps, pegawai ASN dihimpun dalam organisasi/korps profesi. Korps profesi pegawai ASN memiliki tujuan menjaga kode etik profesi dan standar pelayanan profesi ASN dan mewujudkan jiwa korps ASN sebagai pemersatu bangsa. Dalam mencapai tujuan tersebut, korps profesi ASN memiliki fungsi; (a) Pembinaan dan pengembangan profesi ASN; (b) Memberikan perlindungan hukum dan advokasi kepada anggota korps profesi ASN terhadap dugaan pelanggaran sistem merit dan mengalami masalah hukum dalam melaksanakan tugas; (c) Memberikan rekomendasi kepada majelis kode etik instansi pemerintah terhadap pelanggaran kode etik profesi dan kode perilaku profesi; (d) Menyelenggarakan usaha untuk peningkatan 
kesejahteraan anggota korps profesi ASN sesuai dengan ketentuan Per-UU.

ASN sebagai profesi berlandaskan pada kode etik dan kode perilaku dalam menjalankan tugasnya sebagai pelayan publik. Kode etik dan kode perilaku diperlukan dengan tujuan untuk menjaga martabat dan kehormatan para pegawai ASN. Kode etik dan kode perilaku tertuang dalam Bab II Pasal 5 UU Nomor 5 Tahun 2014 berisi pengaturan perilaku agar pegawai ASN;

1. Melaksanakan tugasnya dengan jujur, bertanggungjawab, dan berintegritas tinggi.

2. Melaksanakan tugasnya dengan cermat dan disiplin.

3. Melayani dengan sikap hormat, sopan, dan tanpa tekanan.

4. Melaksanakan tugasnya sesuai dengan ketentuan peraturan perundang-undangan.

5. Melaksanakan tugasnya sesuai dengan perintah atasan atau pejabat yang berwenang sejauh tidak bertentangan dengan ketentuan peraturan perundang-undangan dan etika pemerintahan.

6. Menjaga kerahasiaan yang menyangkut kebijakan negara.

7. Menggunakan kekayaan dan barang milik negara secara bertanggung jawab, efektif, dan efisien.

8. Menjaga agar tidak terjadi konflik kepentingan dalam melaksanakan tugasnya.

9. Memberikan informasi secara benar dan tidak menyesatkan kepada pihak lain yang memerlukan informasi terkait kepentingan kedinasan.

10. Tidak menyalahgunakan informasi intern negara, tugas, status, kekuasaan, dan jabatannya untuk mendapat atau mencari keuntungan atau manfaat bagi diri sendiri atau untuk orang lain.

11. Memegang teguh nilai dasar asn dan selalu menjaga reputasi dan integritas ASN.

12. Melaksanakan ketentuan peraturan perundangundangan mengenai disiplin pegawai ASN.

Untuk mengembangkan dan meningkatkan kompetensi pegawai ASN perlu manajemen ASN yang profesional dan terintegrasi (unified sytem). Manajemen ASN harus dilaksanakan berdasarkan asas "merit", dimana sistem merit menekankan adanya kompetensi terhadap pekerjaan dan menolak patronage terkait dengan koneksi politik dan loyalitas (Prasojo dan Rudita, 2014:15). Untuk mendukung demokrasi yang menerapkan checks and balances ASN harus independent dan a-politic, tujuannya agar pegawai ASN dapat menyelenggarakan fungsi-fungsi pemerintahan dan memberikan pelayanan publik secara profesional tanpa intervensi politik. Penempatan seorang pegawai ASN pada jabatan maupun mutasi pada jabatan lain dilakukan sesuai prinsip merit, artinya harus sesuai dengan kualifikasi serta kompetensi yang dimiliki oleh pegawai ASN. Sedangkan untuk menjamin sistem merit ASN, dibentuk Komisi Aparatur Sipil Negara/KASN (Civil Service Commission atau Public Service Commission) yang anggotanya ditetapkan oleh Presiden.

Pengangkatan dan penetapan pegawai ASN dalam jabatan ditentukan berdasarkan pada perbandingan obyektif antara kualifikasi kompetensi pegawai dengan kualifikasi dan kompetensi yang diperlukan untuk jabatan. Setiap jabatan tertentu dimaksud dikelompokkan dalam klasifikasi jabatan ASN yang menunjukkan kesamaan karakteristik, mekanisme, dan pola kerja. Hal ini sebagaimana dikatakan Coggburn yang menekankan bahwa sistem rekrutmen jabatan publik dalam manajemen SDM dimasa mendatang hendaknya memperhatikan prinsip-prinsip civil service yaitu merekrut aparat yang qualified untuk menangani pekerjaan-pekerjaan di sektor publik yang bisa memberikan jasa kepada mereka secara adil, pengembangan diri, serta memerlakukan peraturan yang memungkinkan bagi mereka untuk dapat mencapai tujuan-tujuan publik (Keban, 2008:111). Disamping itu sistem rekrutmen dalam Jabatan ASN dilaksanakan secara terbuka, independen, dan profesional. Sistem promosi jabatan dilakukan secara transparan dan memberikan kesempatan kepada setiap calon yang memenuhi syarat kompetensi untuk melamar. Dalam konteks NKRI dan guna mengurangi kooptasi politik, sistem promosi jabatan dibuka antar instansi, baik Pusat, Provinsi, Kabupaten, dan Kota dengan mengunakan instrument assessment centre (Jawa Pos, 30 juli 2012).

Kemudian untuk menjamin efisiensi, efektivitas, dan akurasi pengambilan keputusan dalam manajemen ASN diperlukan sistem informasi ASN. Sistem Informasi ASN diselenggarakan secara nasional dan terintegrasi antar instansi pemerintah. Untuk menjamin keterpaduan dan akurasi data sistem informasi ASN, setiap instansi pemerintah wajib memutakhirkan data pegawai ASN secara berkala. Sistem informasi ASN harus berbasis teknologi informasi yang mudah diaplikasikan, mudah diakses, dan memiliki sistem keamanan yang dipercaya. Sistem informasi ASN memuat seluruh informasi dan data pegawai ASN di seluruh instansi pemerintah, baik Pusat maupun Daerah. Data tersebut meliputi; riwayat hidup, pendidikan formal dan non formal, jabatan dan kepangkatan, penghargaan (tanda jasa/kehormatan), pengalaman berorganisasi, gaji, pendidikan dan latihan, daftar penilaian prestasi kerja, surat keputusan, dan kompetensi. Semua informasi tentang ASN harus dapat diakses oleh seluruh pegawai ASN dengan mudah yang disajikan secara akurat, sistematis, dan akuntabel.

\section{Pembinaan Aparatur Sipil Negara}

Pembinaan seringkali diartikan sebagai upaya memelihara dan membawa suatu keadaan yang seharusnya terjadi atau menjaga keadaan 
sebagaimana seharusnya. Menurut Thoha pembinaan adalah suatu proses, hasil atau pertanyaan menjadi lebih baik, dalam hal ini mewujudkan adanya perubahan, kemajuan, peningkatan, pertumbuhan, evaluasi atau berbagai kemungkinan atas sesuatu (Septiyuslianisa, 2014:684). Untuk mencapai tujuan pembinaan diperlukan inisiatif dan perencanaan trategis yang diperlukan untuk memulai perjalanan dan menutup kesenjangan antara kinerja pegawai dengan target organisasi yang akan dicapai sebagai tujuan. Pembinaan pegawai dalam rekrutmen atau penempatan jabatan harus disesuaikan dengan pendidikan, keterampilan, dan keahlian (Dwiputranti dan Sanusi, 2012:115). Hal ini untuk mendapatkan pegawai yang kompeten dalam sebuah institusi. Untuk mendapatkan SDM yang kompeten membutuhkan regresi yang linier antara pendidikan, keterampilan, dan kecerdasan (Abdullah, 2013: 123).

Pengertian lain tentang pembinaan dikemukakan oleh Foster dan Seeker, dalam buku berjudul "Coaching For Peak Employee Performance”, bahwa pembinaan (coaching) adalah upaya berharga untuk membantu orang lain mencapai kinerja puncak (Herman, 2004:7). Foster dan Seeker mengatakan bahwa tidak ada orang yang datang ke tempat kerja menginginkan kinerja buruk dan apabila diberi pilihan orang ingin menjadi sukses di tempat kerja. Seorang pembina menurut Foster dan Seeker harus: (a) Memastikan pelatihan yang tepat dari anggota tim; (b) Memberi sumber daya yang dibutuhkan; (c) Mencari cara untuk membantu; (d) Mengetahui preferensi pribadi semua anggota tim; (e) Menyampaikan informasi; (f) Memberi umpan balik yang konstruktif; (g) Memfasilitasi pemecahan masalah; (h) Memberi arahan dan dukungan yang tepat (Herman, 2004:8-9). Intinya pembinaan mengandung makna sebagai pembaharuan yaitu usaha untuk membuat sesuatu menjadi lebih sesuai atau cocok dengan kebutuhan dan menjadi lebih baik dan lebih bermanfaat.

Sedangkan menurut Malthis pembinaan pegawai adalah suatu kegiatan yang berkaitan dengan peningkatan kecakapan pegawai guna pertumbuhan yang berkesinambungan didalam organisasi (Mohede, 2013: 3). Sedangkan istilah pembinaan dalam administrasi kepegawaian diberikan pengertian luas, meliputi berbagai unsur kegiatan seperti pengembangan karier, perpindahan, pendidikan dan latihan, sampai dengan kesejahteraan, intinya sebagai proses pembentukan sosok pegawai yang diinginkan oleh organisasi. Suatu organisasi yang menetapkan pembinaan sebagai bagian dari pegembangan pegawai sehari-hari, dapat memetik beberapa manfaat, yaitu lebih banyak pegawai yang berprestasi menonjol dengan mengurangi turnover dan meningkatkan hubungan antar pribadi. Upaya dari organisasi publik dan swasta yang menekankan kepada karyawan ataupun pegawainya untuk dibina lebih mendalam melalui pengembangan pegawai, yang dimaksudkan akan memberikan pengaruh pada kinerja dan memberikan output dan outcome bagi organisasi yang menguntungkan sebagai efek jangka panjangnya (Rahman, 2010:1).

Dengan demikian dapat dimaknai pembinaan ASN intinya segala usaha kegiatan manajemen mulai dari perencanaan, pengorganisasian, penggunaan dan pemeliharaan pegawai ASN dengan tujuan untuk dapat melaksanakan tugas pemerintahan yang efektif dan efisien. Pembinaan pegawai ASN dilakukan untuk menghasilkan pegawai yang bermutu dan berkualitas serta berdaya guna dan berhasil guna, yang dilakukan secara sistematis dengan pemanfaatan potensi dan kemampuan sesuai kebutuhan unit instansi pemerintah. Dalam UU Nomor 5 Tahun 2014, bahwa manajemen ASN merupakan pengelolaan ASN untuk menghasilkan pegawai ASN yang profesional, memiliki nilai dasar, etika profesi, bebas dari intervensi politik, bersih dari praktik KKN. Manajemen ASN merupakan keseluruhan upaya untuk meningkatkan efisiensi, efektivitas dan derajat profesionalisme penyelenggaraan tugas, fungsi, dan kewajiban kepegawaian, yang meliputi perencanaan, pengadaan, pengembangan kualitas, penempatan, promosi, penggajian, kesejahteraan, dan pemberhentian.

Berdasarkan studi literatur dari UU Nomor 5 Tahun 2014, bahwa pembinaan pegawai ASN melalui manajemen ASN guna mengembangkan karier dilakukan berdasarkan kualifikasi, kompetensi, penilaian kinerja, dan kebutuhan instansi pemerintah yang dilakukan dengan mempertimbangkan integritas dan moralitasnya. Untuk menjamin keselarasan potensi pegawai ASN dengan kebutuhan penyelenggaraan tugas pemerintahan dan pembangunan perlu disusun pola karier ASN yang terintegrasi secara nasional. Pembinaan manajemen ASN baik di Instansi Pusat maupun Daerah dilakukan secara nasional dalam satu kerangka manajemen ASN yang dilakukan Pemerintah Pusat (unified system). Penyelenggaran manajemen ASN harus berdasarkan prinsip merit, yaitu pelaksanan manajemen ASN yang berdasarkan pada kualifikasi, kompetensi, dan kinerja secara adil dan wajar tanpa membedakan latar belakang politik, ras, warna kulit, agama, asal usul, jenis kelamin, status pernikahan, umur, atau kondisi kecacatan. Manajeman ASN pada jajaran birokrasi pemerintahan dilakukan secara profesional, yang memungkinkan bagi para pegawai ASN untuk lebih maju dalam kariernya dan lebih berkualitas dalam menjalankan tugas pokoknya.

Berdasarkan hasil FGD, bahwa untuk meningkatkan kualitas dan karier untuk pegawai ASN perlu dibangun kembali perangkat dan sistem pengelolaan kepegawaian secara intensif. Perangkat itu mulai dari sistem perencanaan, sistem kompensasi atau penggajian, sistem penilaian kinerja, dan pola pengembangan pegawai ASN yang meliputi pengembangan kualitas dan pola pengembangan 
kariernya. Pengembangan kualitas berkaitan dengan peningkatan kompetensi, sedangkan pengembangan karier berkaitan dengan kedudukan jabatan. Sistem pembinaan karier pegawai ASN harus disusun sedemikian rupa, sehingga menjamin terciptanya kondisi objektif yang dapat mendorong peningkatan prestasi pegawai. Hal tersebut dapat dimungkinkan apabila penempatan pegawai ASN didasarkan atas tingkat keserasian antara persyaratan jabatan dengan kinerja pegawai yang bersangkutan. Dalam manajemen ASN terdapat pola pembinaan karier pegawai untuk meningkatkan kompetensi dan profesionalitasnya.

Menurut Hardianto sistem pembinaan karier pegawai hakekatnya adalah upaya sistematik, terencana yang mencakup struktur dan proses yang keselarasan kompetensi pegawai dengan kebutuhan organisasi (Ihsan, http://coretanaceh.blogspot.com). Menurutnya komponen yang terkait dengan sistem pembinaan karier pegawai meliputi;

1. Misi, sasarana, dan prosedur organisasi; merupakan indikator umum kinerja serta kebutuhan prasarana dan sarana termasuk kebutuhan kualitatif dan kuantitatif SDM.

2. Peta jabatan, yang merupakan refleksi komposisi jabatan; secara vertikal menggambarkan struktur kewenangan tugas dan tanggungjawab jabatan, secara horisontal menggambarkan pengelompokkan jenis dan spesifikasi tugas organisasi.

3. Standar kompetensi; tingkat kebolehan, lingkup tugas dan syarat jabatan yang harus dipenuhi untuk menduduki suatu jabatan agar dapat tercapai sasaran organisasi yang menjadi tugas, hak, kewajiban dan tanggungjawab pemangku jabatan.

4. Alur karier, yaitu pola alternatif lintasan perkembangan dan kemajuan pegawai sepanjang pengabdiannya dalam organisasi.

Dalam melaksanakan manajemen ASN, pendektan SDM yang perlu ditinjolkan bahwa pegawai ASN mempunyai peranan vital dalam organisasi pemerintah. Manajemen ASN harus diperbaiki dan dibangun dengan menerapkan prinsipprinsip manajemen modern yang menekankan pada kualitas SDM ASN. Pendekatan ini bertolak dari pentingnya kedudukan, peran, dan fungsi pegawai ASN sebagai human capital untuk mewujudkan pemerintahan yang baik. Dengan human capital yang tangguh secara umum akan merujuk pada gabungan antara kapabilitas, pengalaman, kompetensi, sikap, dan perilaku manusia yang bisa diubah menjadi hasil (output) yang dapat dinilai dan diukur dengan jelas (Rees dan Mc. Bain, 2007:33). Hal ini menunjukan bila birokrasi pemerintah ingin berkualitas, maka harus memprioritaskan pada pembinaan ASN dalam rangka untuk meningkatkan kompetensinya.
Berdasarkan hasil FGD, bahwa pengembangan ASN menyangkut pada peningkatan secara potensi internal kemampuan diri pegawai ASN yang didasarkan fakta bahwa mereka membutuhkan serangkaian pengetahuan, keahlian dan kemampuan yang berkembang untuk bekerja dengan baik dalam suksesi posisi yang ditemui selama karier. Dalam hal ini merupakan persiapan karier jangka panjang seorang pegawai ASN, namun demikian perencanaan karier jangka pendek dan menengahnya juga diperhatikan. Sehingga cakupan pengembangan ASN selanjutnya akan terkait dengan sistem karier yang diterapkan oleh unit organisasi di lokal unitnya, maupun karier organisasi pemerintah secara nasional. Pentingnya pola karier ini untuk memudahkan kejelasan bagi setiap pegawai ASN untuk dapat mengakses sistem karier yang ada, baik secara unit kerja instansi maupun nasional dalam rangka melaksanakan kerja pemerintahan secara umum. Presiden selaku kepala pemerintahan memegang kekuasaan tertinggi dalam pembinaan ASN di seluruh lembaga negara.

Pada saat melaksanakan pembinaan pegawai ASN Presiden selaku pimpinan tertinggi dalam pembinaan ASN secara teknis akan mengalami kesulitan bila dilaksanakan sendiri. Oleh karena itu dalam melakukan pembinaan pegawai ASN, sebagian dari tanggungjawab pembinaan dan wewenang tugas didelegasikan kepada pimpinan instansi di masingmasing unit instansi yaitu pada Pemerintah Pusat (Lembaga Kementerian dan Lembaga Non Kementerian), Lembaga Non Struktural, Pemerintah Provinsi, Pemerintah Kabupaten, dan Pemerintah Kota. Apabila tugas dan wewenang Pejabat Pembina Kepegawaian tertinggi tidak didelegasikan justru akan menyulitkan dalam pembinaan pegawai ASN tersebut, hal ini mengingat jumlah pegawai ASN yang cukup banyak. Disamping itu bila pembinaan ASN tidak didelegasikan, justru akan menghambat tugas-tugas Presiden dalam menjalankan pemerintahan, mengingat tugas Presiden sangat luas dan komplek. Dengan pendelegasian Pembinaan ASN kepada pimpinan instansi sebagai Pejabat Pembina Kepegawaian diharapkan pegawai ASN mudah dipantau dalam pembinaannya.

Berdasarkan studi literatur, bahwa ketentuan diatas diatur dalam Bab VII Pasal 25 Ayat 2 UU Nomor 5 yang menyebutkan, bahwa Presiden selaku pemegang kekuasaan tertinggi pembinaan pegawai ASN dapat mendelegasikan kewenangan dalam menetapkan pengangkatan, pemindahan, dan pemberhentian pejabat selain Pejabat Pimpinan Tinggi Utama dan Madya, serta Pejabat Fungsional Keahlian Utama kepada Menteri di Kementerian, Pimpinan Lembaga di Lembaga Pemerintah Non Kementerian, Sekretaris Jenderal di Sekretariat Lembaga Negara dan Lembaga Non Struktural, Gubernur di Provinsi; dan Bupati/Walikota di Kabupaten/ Kota. Disamping itu Presiden juga dapat 
mendelegasikan kewenangan pembinaan manajemen ASN kepada Pejabat Berwenang di Kementerian, Sekretaris Jenderal atau Sekretariat Lembaga Negara, Sekretariat Lembaga Non Struktural, Sekretaris Daerah Provinsi dan Kabupaten/Kota. Dalam manajemen ASN fungsi pimpinan instansi sebagai Pejabat Pembina Kepegawaian sangat strategis yang mempunyai kewenangan menetapkan pengangkatan, pemindahan, dan pemberhentian pegawai ASN.

Pimpinan instansi dalam melaksanakan tugasnya punya peran penting dalam mengendalikan setiap kegiatan untuk mendapatkan, menempatkan, memelihara, membina, mengembangkan, dan menggunakan pegawai ASN guna mencapai tujuan organisasi. Fungsi ini meliputi perencanaan, pengorganisasian, pengawasan dan penilaian terhadap kegiatan-kegiatan disetiap instansi pemerintahan. Dengan demikian setiap pimpinan instansi pemerin-tahan punya tanggungjawab dalam melakukan pembinaan pegawai ASN. Disamping itu pimpinan instansi dalam melaksanakan pembinaan pegawai ASN terlebih dahulu perlu mengetahui sasaran dari pembinaan yang menjadi sekala prioritas. Sasaran pembinaan dapat diklasifikasikan pada tiga sasaran pokok, yaitu pada pembinaan karier, kompetensi, dan disiplin. Keberhasilan pembinaan pegawai ASN disamping untuk mengetahui sasaran, juga dapat mengetahui teknikteknik pembinaan yang kontinyu sebagai pedoman dalam menyelenggarakan pembinaan pegawai ASN selanjutnya. Hal ini perlu dilakukan agar tujuan pembinaan ASN dapat tercapai secara maksimal, sehingga bisa mendapatkan pegawai ASN yang kompeten dan punya daya saing.

\section{Peran Pejabat Pembina Kepegawaian}

Sebagaimana dijelaskan dalam ketentuan umum UU Nomor 5 Tahun 2014 bahwa Pejabat Pembina Kepegawaian adalah pejabat yang mempunyai kewenangan menetapkan pengangkatan, pemindahan, dan pemberhentian pegawai ASN dan pembinaan manajemen ASN di instansi pemerintah sesuai dengan ketentuan peraturan perundangundangan. Presiden selaku pemegang kekuasaan tertinggi pembinaan ASN dapat mendelegasikan kewenangan menetapkan pengangkatan, pemindahan, dan pemberhentian pejabat selain pejabat pimpinan tinggi utama dan madya, dan pejabat fungsional keahlian utama kepada;

Menteri di Kementerian.

1. Pimpinan lembaga di lembaga pemerintah nonkementerian.

2. Sekretaris Jenderal di Sekretariat Lembaga Negara dan Lembaga Non Struktural.

3. Gubernur di Provinsi.

4. Bupati/Walikota di Kabupaten/Kota.

Berdasarkan hasil FGD, bahwa untuk melaksanakan salah satu fungsi manajemen ASN dalam pengembangan, peningkatan kompetensi, dan pemenuhan kebutuhan setiap pegawai ASN, seorang Pejabat Pembina Kepegawaian mempunyai kewenangan untuk mengangkat, memindahkan, mempromosikan, dan memberhentikan pegawai ASN. Pengangkatan ASN di instansi pemerintah menjadi wewenang dan tanggungjawab Pejabat Pembina Kepegawaian di masing-masing instansi pemerintah. Pengadaan pegawai ASN dilakukan oleh Pejabat Berwenang dengan membentuk Tim Seleksi terlebih dahulu. Tim kemudian melakukan perencanaan, pengumuman lowongan ASN, pelamaran, seleksi, pengumunan hasil seleksi, pengangkatan calon ASN sampai dengan pengangkatan menjadi pegawai ASN. Dalam menetapkan pengangkatan pegawai ASN, Pejabat Pembina Kepegawaian tidak boleh melanggar prosedur sebagaimana telah dilakukan oleh Tim.

Kemudian apabila proses rekrutmen atau pengadaan pegawai ASN telah selesai, maka hasilnya diserahkan kepada Pejabat Pembina Kepegawaian. Kemudian Pejabat Pembina Kepegawaian mengumumkan pelamar yang dinyatakan lulus ujian penyaringan kemudian mengangkat dan menetapkan sebagai calon pegawai ASN. Pejabat Pembina Kepegawaian tidak mempunyai hak atas segala proses pengadaan pegawai ASN secara teknis karena itu menjadi tugas dan tanggung jawab dari Pejabat Yang Berwenang. Pejabat Yang Berwenang bertanggungjawab atas seluruh proses seleksi dan pengadaan pegawai ASN dengan menerapkan sistem merit. Sebelum melakukan pengadaan pegawai ASN, setiap instansi pemerintah harus melakukan penyusunan, pemetakan, dan penetapan kebutuhan ASN. Setiap instansi pemerintah wajib menyusun kebutuhan jumlah dan jenis jabatan ASN berdasarkan analisis jabatan dan analisis beban kerja.

Penyusunan kebutuhan jumlah dan jenis jabatan ASN dilakukan untuk jangka waktu 5 (lima) tahun yang diperinci per 1 (satu) tahun berdasarkan prioritas kebutuhan. Berdasarkan penyusunan kebutuhan tersebut, maka Menteri PAN RB akan menetapkan kebutuhan jumlah dan jenis jabatan PNS secara nasional maupun secara terperinci per instansi pemerintah. Pengadaan ASN merupakan kegiatan untuk mengisi kebutuhan Jabatan Administrasi atau Jabatan Fungsional dalam suatu Instansi Pemerintah. Pejabat Pembina Kepegawaian berperan pokok dalam pengambilan kebijakan penyusunan kebutuhan pegawai ASN di instansinya sesuai ketentuan yang ada dalam UU Nomor 5 Tahun 2014. Setiap instansi pemerintah wajib merencanakan dan melaksankan pengadaan pegawai ASN secara profesional dengan menerapkan sistem merit.

Berdasarkan studi literatur, bahwa di UU Nomor 5 tahun 2014 dinyatakan bahwa dalam proses mutasi dan promosi jabatan ASN, peran Pejabat Pembina Kepegawaian adalah menetapkan pejabat berdasarkan hasil seleksi yang dilakukan oleh Pejabat 
Yang Berwenang. Untuk mutasi dan promosi Pejabat Administrasi dan Pejabat Fungsional, Pejabat Pembina Kepegawaian terlebih dahulu harus minta pertimbangan dari tim penilai kinerja PNS pada Instansi Pemerintah yang dibentuk oleh Pejabat Yang Berwenang. Tim seleksi jabatan melakukan seleksi dengan prinsip merit yang memperhatikan syarat kompetensi, kualifikasi, kepangkatan, pendidikan dan latihan, rekam jejak jabatan, integritas, dan penilaian uji kompetensi melalui pusat penilaian (assesment center). Khusus untuk pengisian Jabatan Pimpinan Tinggi yang dilakukan oleh Pejabat Pembina Kepegawaian terlebih dahulu membentuk panitia seleksi Instansi Pemerintah dan berkoordinasi dengan KASN. KASN merupakan Lembaga Pemerintah Non Struktural punya kewenangan untuk mengawasi setiap tahapan proses pengisian Jabatan Pimpinan Tinggi mulai dari pembentukan Tim seleksi instansi, pengumuman lowongan, pelaksanaan seleksi, pengusulan nama calon, penetapan, dan pelantikan.

Instansi pemerintah baik Pusat maupun Daerah wajib memberitahukan kepada KASN, bila akan melakukan mutasi atau promosi Jabatan Pimpinan Tinggi. Atas dasar pemberitahuan dari Tim instansi, maka KASN melakukan pengawasan terhadap seluruh proses mutasi dan pengangkatan Jabatan Pimpinan tinggi tersebut. Berdasarkan hasil pengawasan, KASN dapat merekomendasikan kepada Presiden untuk menjatuhkan sanksi terhadap Pejabat Pembina Kepegawaian dan Pejabat Yang Berwenang yang melanggar prinsip merit dan ketentuan peraturan perundang-undangan. Pejabat Pembina Kepegawaian hanya diperbolehkan memilih 3 (tiga) calon Pejabat Pimpinan Tinggi ASN yang diajukan oleh Pejabat Yang Berwenang dari hasil seleksi jabatan. Disamping itu Pejabat Pembina Kepegawaian juga tidak boleh mengganti Jabatan Pimpinan Tinggi ASN sebelum Pejabat Pimpinan Tinggi tersebut melaksanakan tugasnya selama 2 tahun. Kemudian sebelum masa jabatannya berakhir dalam kurun waktu 6 (enam) bulan, Pejabat Pembina Kepegawaian juga tidak diperkenankan mengganti atau memutasi Pejabat Pimpinan Tinggi yang ada pada instansi pemerintah.

\section{Peran Pejabat Yang Berwenang}

Sebagaimana dijelaskan dalam ketentuan umum UU Nomor 5 Tahun 2014 bahwa Pejabat Yang Berwenang adalah pejabat yang mempunyai kewenangan melaksanakan proses pengangkatan, pemindahan, dan pemberhentian pegawai ASN sesuai dengan ketentuan peraturan perundang-undangan. Presiden dapat mendelegasikan kewenangan pembinaan manajemen ASN kepada Pejabat Yang Berwenang di Kementerian, Sekretaris Jenderal/ Sekretariat Lembaga Negara, Sekretariat Lembaga Non Struktural, Sekretaris Daerah Provinsi dan Kabupaten/Kota. Pejabat Yang Berwenang dalam menjalankan fungsi manajemen ASN harus menerapkan sistem merit dan berkonsultasi dengan Pejabat Pembina Kepegawaian. Pejabat Yang Berwenang berperan mengusulkan pengangkatan, pemindahan/mutasi, serta pemberhentian Pejabat Administrasi dan Pejabat Fungsional kepada Pejabat Pembina Kepegawaian di instansi masing-masing.

Berdasarkan hasil FGD, bahwa peran Pejabat Yang Berwenang dalam sistem pengadaan ASN memberikan rekomendasi hasil seleksi kepada Pejabat Pembina Kepegawaian di instansi masingmasing. Setiap warga negara Indonesia mempunyai kesempatan yang sama untuk melamar menjadi pegawai ASN setelah memenuhi segala persyaratan yang telah ditentukan. Setiap instansi pemerintah melalui Pejabat Berwenang wajib mengumumkan secara terbuka kepada publik dengan media tentang adanya kebutuhan formasi ASN. Penyelenggaraan seleksi dan pengadaan pegawai ASN dilaksanakan melalui penilaian objektif berdasarkan kompetensi, kualifikasi, dan persyaratan lain yang dibutuhkan oleh jabatan yang dilamar. Penyelenggaraan seleksi pengadaan ASN paling tidak melalui 3 (tiga) tahapan yaitu seleksi administrasi, seleksi kompetensi dasar, dan seleksi kompetensi bidang. Metode seleksi pegawai ASN dilaksanakan secara profesional yang menghindari terjadinya kecurangan dalam setiap tahapan seleksi. Peserta yang lolos seleksi diangkat menjadi calon pegawai ASN yang ditetapkan secara syah dengan keputusan Pejabat Pembina Kepegawaian.

Setelah ditetapkan sebagai calon pegawai ASN, maka seluruh calon pegawai ASN tersebut wajib menjalani masa percobaan yang dilaksanakan melalui proses pendidikan dan pelatihan terintegrasi. Hal ini dilaksanakan untuk membangun integritas moral, kejujuran, semangat serta motivasi nasionalisme dan kebangsaan, karakter kepribadian yang unggul dan bertanggungjawab, serta memperkuat profesionalisme dan kompetensi bidang. Oleh karena itu Pejabat Yang Berwenang berperan menyelenggarakan proses pendidikan dan pelatihan bagi calon pegawai ASN yang sedang menjalani masa percobaan. Pelaksanaan pendidikan dan pelatihan tersebut dapat dilaksanakan setelah berkoordinasi dan mendapatkan persetujuan dengan Pejabat Pembina Kepegawaian. Bagi calon pegawai ASN yang lolos menjalani masa percobaan serta dinyatakan sehat jasmani dan rohani, maka dapat diangkat menjadi pegawai ASN oleh Pejabat Pembina Kepegawaian sesuai dengan ketentuan peraturan perundang-undangan.

Promosi jabatan merupakan salah satu bentuk pengembangan karier SDM ASN yang dilaksanakan dengan mempertimbangkan integritas dan moralitas. Sebagaimana dikatakan Effendi (2010:129) bahwa pengembangan SDM aparatur negara diperlukan untuk menghadapi perubahanperubahan strategis pada dasarnya adalah pembangunan SDM PNS yang profesional, netral 
dari kegiatan poltik, berwawasan global, bermoral tinggi, serta berkemampuan sebagai penyangga persatuan dan kesatuan bangsa. Konsekuensi dari itu, maka semua pegawai ASN dalam jajaran pemerintahan dituntut untuk meningkatkan kualitasnya dengan kemampuan, kecakapan, dan keterampilan yang diikuti dengan ketaatan pada aturan (disiplin) serta moral dan etika. Sarana untuk meningkatkan kualitas dalam mensukseskan karier bagi para pegawai ASN dilingkungan instansi pemerintahan yang paling pokok adalah melalui program pengembangan PNS secara tepat.

Dalam promosi pegawai ASN, Pejabat Yang Berwenang melaksanakan seleksi menerapkan sistem merit dengan membentuk Panitia Seleksi. Promosi dilakukan berdasarkan perbandingan objektif antara kompetensi yang dimiliki calon dengan kompetensi yang dipersyaratkan untuk jabatan. Disamping itu juga memperhatikan hasil penilaian prestasi kerja, kepemimpinan, kerjasama, kreativitas, serta pertimbangan dari Tim Penilai Kinerja pegawai ASN pada Instansi masing-masing. Tim penilai kinerja pegawai ASN dibentuk oleh Pejabat Yang Berwenang yang mendasarkan pada aspek kualitas, kompetensi, integritas, dan pengalaman. Promosi pegawai ASN harus obyektif, tidak diskriminatif, politik, transparan tanpa membedakan gender, suku, agama, ras, dan golongan. Promosi Pejabat Administratif dan Pejabat Fungsional dilakukan oleh Pejabat Berwenang setelah mendapat pertimbangan Tim Penilai Kinerja Pegawai ASN pada instansi masing-masing. Tim Penilai Kinerja pegawai ASN dibentuk oleh pimpinan instansi masing-masing sesuai ketentuan yang mengatur tentang kinerja ASN. Untuk penilaian kinerja pegawai ASN, kewenangannya ada pada Pejabat Berwenang pada instansi masing-masing.

Penilaian kinerja ASN didelegasikan secara berjenjang kepada atasan langsung dari pegawai ASN. Penilaian kinerja pegawai ASN dapat juga dilakukan oleh bawahan kepada atasannya. Pejabat Yang Berwenang disetiap instansi pemerintah wajib menyelenggarakan dan memantau pelaksanaan penilaian kinerja ASN secara obyektif dan transparan. Penilaian kinerja pegawai ASN dilakukan berdasarkan perencanaan kinerja pada tingkat individu dan tingkat unit/organisasi, dengan memperhatikan target, sasaran, hasil, dan manfaat yang dicapai. Penilaian kinerja pegawai ASN dilakukan secara objektif, terukur, akuntabel, partisipasi, dan transparan. Hasil penilaian prestasi kerja atau kinerja pegawai ASN disampaikan kepada Tim Penilai Kinerja pegawai ASN. Hasil penilaian kinerja Pegawai ASN dimanfaatkan untuk menjamin objektivitas dalam pengembangan aparatur, dan untuk selanjutnya dijadikan sebagai persyaratan dalam pengangkatan jabatan dan kenaikan pangkat, pemberian tunjangan dan sanksi, mutasi, dan promosi, serta untuk mengikuti pendidikan dan pelatihan.

\section{Implementasi Pembinaan ASN-PNS}

Sebelum UU Nomor 5 Tahun 2014 pembinaan pegawai ASN khususnya PNS diatur dalam UU Nomor 43 Tahun 1999 tentang PokokPokok Kepegawaian. Dalam pembinaan PNS sebagaimana diatur dalam UU Nomor 43 Tahun 1999 tersebut dinyatakan bahwa manajemen PNS diarahkan untuk menjamin penyelenggaraan tugas pemerintahan dan pembangunan secara berdayaguna dan berhasil guna. Untuk mewujudkan hal tersebut, maka diperlukan PNS yang profesional, bertanggungjawab, jujur dan adil melalui pembinaan yang dilaksanakan berdasarkan sistem prestasi kerja dan sistem karier yang dititikberatkan pada sistem prestasi kerja. Sistem karier adalah suatu sistem kepegawaian dimana untuk pengangkatan jabatan didasarkan atas kecakapan yang bersangkutan, sedangkan dalam pengembangan lebih lanjut, masa kerja, pengalaman, kesetiaan, pengabdian, dan syarat-syarat obyektif lainnya juga turut menentukan. Sistem prestasi kerja adalah sistem kepegawaian dimana untuk mengangkat seseorang dalam suatu jabatan didasarkan atas kecakapan dan prestasi yang telah dicapainya dan dapat dibuktikan secara nyata.

Untuk merespon berbagai isu tentang penyelenggaraan pemerintahan dalam mewujudkan reformasi birokrasi, pemerintah bersama Dewan Perwakilan Rakyat (DPR) telah menetapkan UU Nomor 5 Tahun 2014 Tentang Aparatur Sipil Negara. UU ini sebagai pengganti UU Nomor 8 Tahun 1974 Tentang Pokok Pokok Kepegawaian sebagaimana telah diubah dalam UU Nomor 43 Tahun 1999. Lahirnya UU Nomor 5 Tahun 2014 merupakan modal dasar untuk mewujudkan cita-cita reformasi birokrasi dibidang human capital ASN. Landasan filosofis UU Nomor 5 Tahun 2014 salah satu untuk memperbaiki manajemen ASN dengan harapan terjadi peningkatan kompetensi ASN. Penyelenggaraan manajemen ASN menekankan pada aspek pembinaan pegawai dengan diharapkan dapat menghasilkan pegawai ASN yang kompeten, memiliki nilai dasar, etika profesi, bebas dari intervensi politik, dan bersih dari praktik KKN.

Sistem pembinaan karier pegawai hakekatnya merupakan upaya sistematik dan terencana yang mencakup struktur serta proses yang menghasilkan keselarasan kompetensi pegawai dengan kebutuhan organisasi. Komponen krusial yang terkait dengan sistem pembinaan karier pegawai diantaranya; (a) Peta jabatan, yang secara vertikal menggambarkan struktur kewenangan tugas dan tanggungjawab jabatan dan secara horisontal menggambarkan pengelompokkan jenis dan spesifikasi tugas dalam organisasi; (b) Standar kompetensi, yaitu tingkat kebolehan, lingkup tugas dan syarat jabatan yang harus dipenuhi untuk menduduki jabatan agar dapat tercapai sasaran organisasi yang menjadi tugas, hak, kewajiban dan tanggungjawab dari pemangku jabatan; (c) Alur karier, yaitu pola alternatif lintasan 
perkembangan dan kemajuan pegawai sepanjang pengabdiannya dalam organisasi (Jimmi, https://cerdiknet.wordpress.com). Oleh karena itu sistem pembinaan karier pegawai harus disusun, sehingga menjamin terciptanya kondisi objektif yang dapat mendorong peningkatan prestasi pegawai.

Berdasarkan hasil FGD dan wawancara dengan para informan di 3 (tiga) lokasi penelitian (Kabupaten Lampung Utara, Kota Cilegon, dan Kota Kediri), bahwa terkait pembinaan karier dalam pengangkatan jabatan belum didasarkan pada kecakapan dan kompetensi seorang PNS. Pengangkatan jabatan PNS khususnya jabatan struktural di Kabupaten Lampung Utara justru banyak diwarnai aspek kepentingan politik. Setiap ada pergantian Bupati selalu diikuti dengan pergantian pejabat birokrasi yang mengabaikan prinsip merit. Pengangkatan jabatan lebih didasarkan pada kesesuaian pada kesamaan warna politiknya, bukan pada aspek kualifikasi dan kompetensi. Bupati menempatkan orang-orangnya pada jabatan strategis, seperti Sekda, Kepala Badan Kepegawaian Daerah, Kepala Dinas pekerjaan Umum, Kepala Dinas Pendidikan, Kapala Dinas Kesehatan, dan sebagainya. Di Kota Cilegon pengangkatan jabatan masih didasarkan pada faktor kepentingan ras, dimana putra daerah lebih diunggulkan. Pegawai yang berasal dari Kota Cilegon atau Daerah Banten lebih diprioritaskan menduduki jabatan strategis, diandingkan pegawai yang berasal dari luar Banten seperti Jawa Barat ataupun Jawa pada umumnya. Sedangkan di Kota Kediri pengangkatan jabatan diwarnai aspek integritas dan moralitas Pejabat Politiknya. Jabatan dan kedudukan dihargai dengan materi (uang), siapa yang mau memberikan uang kepada Pejabat Pembina Kepegawaian/ Walikota, maka dialah yang kemungkinan besar mendapatkan jabatan tersebut.

Berdasarkan hasil FGD dan wawancara dengan para informan di 3 (tiga) lokasi penelitian (Kabupaten Lampung Utara, Kota Cilegon, dan Kota Kediri), bahwa pembinan karier PNS terkait dengan peran Pejabat Pembina Kepegawaian dan Pejabat Berwenang masih kurang baik. Peran Pejabat Pembina Kepegawaian lebih dominan menjalankan pembinaan PNS, sedangkan peran Pejabat Yang Berwenang hanya sebatas menjalankan perintah dari Pejabat Pembina Kepegawaian. Dalam pengangkatan jabatan, Pejabat Pembina Kepegawaian tidak menjalankan proses seleksi dengan sistem merit yang independen dan transparan. Hasil mutasi dan promosi jabatan tidak menghasilkan kesesuaian antara kualifikasi yang dibutuhkan jabatan dengan kualifikasi dan kompetensi yang dimiliki pejabat. Di ketiga Pemerintah Daerah tersebut tidak memiliki peta jabatan, standar kompetensi, dan alur karier yang jelas. Oleh karena itu pengangkatan jabatan PNS yang dilakukan, tidak dilaksanakan melalui sistem karier yang jelas sebagaimana dimanatkan dalam berbagai peraturan perundang undangan yang ada.

\section{KESIMPULAN}

Pertama, terdapat perbedaan yang jelas dalam pembinaan ASN, antara peran Pejabat Pembina Kepegawaian dan Pejabat Berwenang. Sistem Pembinaan ASN yang dilakukan Pejabat Pembina Kepegawaian dan Pejabat Berwenang masing-masing mempunyai peran, tugas, fungsi, dan tanggung jawab yang berbeda. Peran Pejabat Pembina Kepegawaian berkaitan dengan masalah-masalah kebijakan (regulasi), sedangkan peran Pejabat Yang Berwenang berkaitan dengan tataran teknis (implementasi). Pejabat Pembina Kepegawaian mempunyai peran kewenangan menetapkan pengangkatan, penempatan, dan pemberhentian pegawai ASN. Sedangkan Pejabat Yang Berwenang mempunyai peran kewenangan melaksanakan proses pengangkatan, pemindahan, dan pemberhentian pegawai ASN berbasis merit sesuai dengan ketentuan peraturan perundang-undangan. Kedua, implementasi pembinaan pegawai ASN (PNS) di instansi pemerintah (Kabupaten Lampung Utara, Kota Cilegon, dan Kota Kediri) tidak berjalan dengan baik. Hal ini dikarenakan terdapat tiga faktor dominan yang menjadi penghambat dalam sistem pembinaan PNS yaitu faktor kepentingan politik, ras, dan integritas/moralitas. Di instansi tersebut, komponen terkait dengan sistem pembinaan karier PNS seperti peta jabatan, standar kompetensi, dan pola karier tidak dimiliki. Disamping itu peran Pejabat Pembina Kepegawaian dan Pejabat Yang Berwenang selama ini juga tidak berjalan efektif, dimana Pejabat Pembina Kepegawaian lebih dominan dalam menjalankan perannya. Adapun rekomendasi penelitian; Pertama, menciptakan kode etik sistem penyelenggaraan pembinaan ASN khususnya untuk Pejabat Pembina Kepegawaian dan peran Pejabat Yang Berwenang, disamping itu dalam mejalankan peran, tugas, dan fungsinya, Pejabat Pembina Kepegawaian dan Pejabat Yang Berwenag harus berkoordinasi, bersinegi, berkomitmen, serta menghargai dan menghormati dalam menjalankan tupoksinya masing-masing. Kedua, lembaga pengawas (Deputi Pengawasan dan Pengendalian BKN) melakukan pemantauan secara intensif terhadap pembinaan pegawai ASN, dan memberikan sanksi tegas terhadap segala bentuk pelanggaran dalam penyelenggaraan manajemen ASN. 


\section{Daftar Pustaka}

Abdullah, Hayat. 2014. Relokasi Kebijakan Fiskal: Implikasi Peningkatan Human Capital dan Pembangunan Infrastruktur Terhadap Pertumbuhan Ekonomi dan Kesejahteraan Masyarakat. Jurnal Bina Praja Volume 6 Nomor 2 Juni 2014. Jakarta: Badan Litbang Kemendagri

Dwiputranti, Septiana dan Sanusi, Anwar. 2012. Evaluasi Kebijakan Dalam Upaya Peningkatan Mutu Human Capital di Sektor Publik (Comparative Dengan Australia) dalam Pengembangan Human Kapital: Perspektif Nasional, Regional, Global, Yogyakarta: Graha Ilmu

Effendi, Sofian. 2010. Reformasi Tata Pemerintahan: Menyiapkan Aparatur Negara Untuk Mendukung Demokratisasi Politik dan Ekonomi Terbuka, Yogyakarta: Gadjah Mada University Press

Herman. 2004. Pengaruh Pembinaan Terhadap Perilaku Pegawai Negeri Sipil, Jakarta: Puslitbang BKN

Ihsan, Muhammad. 2012. Sistem Pembinaan Karir Pegawai Negeri Sipil Yang Profesional Sebagai Upaya Pembentukan Aparatur Yang Bersih Dan Berwibawa.

http://coretanaceh.blogspot.com/2012/10/sistem -pembinaan-karir-pegawai-negeri.html.

(diunduh, 10/4/2014)

Jimmi. 2010. Sistem Pembinaan Pegawai, https://cerdiknet.wordpress.com/

2010/05/08/sistem-pembinaan-karier-pegawai/ (diunduh, 30/12/2014)

Keban, Yeremias T. 2008. Enam Dimensi Strategis Administrasi Publik Konsep Teori dan Isu, Yogyakarta: Gava Media

Mohede, Rezky. 2013. Pembinaan Aparatur Pemerintah Dalam Rangka Meningkatkan Kualitas Kerja (Suatu Studi Di Kecamatan Siau Timur. Jurnal Politico, Volume 1 Nomor 3 Tahun 2013, Manado: FISIP UNSRAT

Rahman, Abdul. 2010. Pengembangan Pegawai Melalui Perencanaan Pelatihan Yang Efektif, Jurnal Borneo Administrator, Volume 6 Nomor 2 Tahun 2010, Samarinda: PKP2A III LAN

Rees, David and Mc. Bain, Richard. 2007. People Management Theori and Strategic, Jakarta: Kencana

Prasojo, Eko dan Rudita, La Ode. 2014. UndangUndang Aparatur Sipil Negara: Membangun Profesionalisme Aparatur Sipil Negara. Civil Service Jurnal Kebijakan dan Manajemen PNS, Volume 8 Nomor 1, Juni 2014, Jakarta: Puskalitpeg BKN

Prasojo, Eko. 2012. Mengubah Kultur Birokrasi, Jawa Pos, 30 Juli 2012

Rakhmawanto, Ajib. 2013. Model Pengangkatan dan Pengembangan Jabatan Pimpinan Tinggi Dalam Rancangan UU ASN, Jakarta: Pesat Pengkajian dan Penelitian BKN
Septiyuslianisa. 2014. Pembinaan Pegawai Dalam Pelaksanaan Tugas Di Biro Umum Kantor Gubernur Provinsi Sumatera Barat, Jurnal Administrasi Pendidikan, Volume 2 Nomor 1, Juni 2014, Padang: FIP UNP

Sugiyono. 2012. Metode Penelitian Kuantitatif, Kualitatif, dan $R \& D$. Cetakan ke-17. Bandung: Alfabeta.

Sulistiyani, Ambar Teguh. 2010. Konflik Kepentingan Dalam Sistem Kepegawaian Publik. Yogyakarta: Graha Ilmu

Wicaksono, Kristian W dan Ismail, Hubertus H. 2013. Penerapan Prinsip-Prinsip Administrasi Dalam Birokrasi Indonesia. Jurnal Bina Praja, Volume 5 Nomor 3, Edisi September 2013, Jakarta: Badan Litbang Kemendagri

Tim Penyusun. 2014. Statistik Pegawai Negeri Sipil Per- Juni 2014, Jakarta: Kedeputian INKA BKN

Tim Penyusun. 2014. Profil Jabatan Fungsional Pegawai Negeri Sipil, Jakarta: Direktorat Jabatan ASN BKN

Tim Penyusun. 2010. Naskah Akademik Undang Undang Aparatur Negara, Jakarta: Kementerian PAN RB

Undang-Undang Nomor 5 Tahun 2014. Tentang Aparatur Sipil Negara, Jakarta: Direktorat Perundang Undangan BKN

Yuslim, Djumadi, Sugandi. 2013. Pembinaan Sumber Daya Aparatur Dalam Meningkatkan PelayananPublik Di Kantor Camat Tenggarong Kabupaten Kutai Kartanegara(Studi Implementasi Peraturan Pemerintah No 42 Tahun 2004 Tentang Pembinaan Korps Dan Kode Etik Pegawai Negeri Sipil). e-Journal Pemerintahan Integrattif, Volume 1, Nomor 1. http://ar.mian.fisipunmul.ac.id/site/wpcontent/uploads/2013/06/Jur nal\%20Yuslim\%20Upload\%20\%2806-04-1303-22-11\%29.pdf 
